www.jmscr.igmpublication.org

Impact Factor 5.84

Index Copernicus Value: 83.27

ISSN (e)-2347-176x ISSN (p) 2455-0450

crossref DOI: _https://dx.doi.org/10.18535/jmscr/v5i7.203

Journal Of Medical Science And Clinical Research

\title{
Functional Outcome of Intervertebral Disc Prolapse Treated with Epidural Steroid and Local Anaesthetic - Prospective Study
}

\author{
Authors \\ Dr Krishnakumar CV ${ }^{1}$, Dr Sabarisree $\mathrm{M}^{2}$, Dr Parthasarathy Naik ${ }^{3}$ \\ ${ }^{1}$ Associate Professor (CAP) in Orthopaedics, Govt Medical College, Thrissur \\ ${ }^{2}$ Associate Professor (CAP) in Orthopaedics, Govt Medical College, Trivandrum \\ ${ }^{3}$ Senior Resident in Orthopaedics, Govt Medical College, Thrissur \\ Corresponding Author \\ Dr Sabarisree M \\ Associate Professor (CAP) in Orthopaedics, Govt Medical College, Trivandrum
}

\section{INTRODUCTION}

Disc prolapse amounts for $5 \%$ of lower back disorders. Intervertebral disc prolapse can be treated conservatively or surgically.

The intervertebral disc is subject to continuous and progressive degenerative changes throughout life, L3,L4,L5 showing greatest degree of degeneration.

Clinical features can be discussed under three headings:

Low backache: Back pain is common in the second decade, disc disease and disc herniation in the third or fourth decade.

Radiculopathy: This refers to pain in the distribution of the sciatic nerve and is invariably due to disc herniation. This is called as sciatica.

Nerve root compression: About 95 percent of the disc prolapse takes place through the L4-5 region compressing the L5 nerve root. The other nerve roots commonly involved are L4 and S1 due to disc prolapse between L3-4 and L5$\mathrm{S} 1$ respectively.
The conservative methods include (1) bed rest (2) anti-inflammatory drugs (3) various forms of physiotherapy (4) manipulation and exercise training (5) corsets (6) epidural nerve

\section{Epidural Steroids}

Epidural steroids are a symptomatic method of treatment, and consist of injecting a long-acting steroid and a local anesthetic into the epidural space. Its effect lasts for three weeks and is useful for sub acute and chronic cases. It also reduces dependence on narcotics in chronic cases.

All about epidural steroid injection:

- In vogue since 1950's.

- Effective in approximately 50 percent patients with low backache.

- It decreases inflammation and flushes out inflammatory proteins thereby reducing pain.

- It helps in better back rehabilitation.

- Maximum of three injections in a year with a two-week gap is given. 
- Adverse features include infection, dural puncture and arachnoiditis.

- It primarily decreases leg pain.

- After the injection, the patient is advised one-day rest.

Mechanism of action of epidural steroids

1. Decreases surrounding edema

2. Sequestration of antigen from disc

There are three different ways to perform an epidural injection:

- Caudal Block

- Translumbar

- Transforaminal

\section{AIMS AND OBJECTIVES}

To study the functional outcome of epidural steroids and local anaesthetics in patients with intervertebral disc prolapse.

\section{MATERIALS AND METHODS}

The study population was the patients with low back ache attending Orthopaedics OPD at Govt. Medical College, Thrissur during the period: 0101-2014 to 31-06-2015.

\section{Inclusion criteria}

Unilateral lumbar radiculopathy clinically or radiologically proved to be due to prolapsed disc

\section{Exclusion criteria}

1) Motor weakness

2) Autonomic damage (bowel and bladder)

3) Massive prolapse without sequestration, pain corresponding to nerve root

4) Scoliosis

5) Developmental dysplasias

6) Cauda equine syndrome

7) Tumours of lumbar region

8) severe paresis,

9) severe pain,

10) previous spinal injection or surgery,

11) deformity,

12) pregnancy,

13) ongoing breast feeding,

14) warfarin therapy,
15) ongoing treatment with non-steroidal antiinflammatory drugs,

16) body mass index $>30$,

17) poorly controlled psychiatric conditions

18) severe comorbidity.

19) severe intraspinal pathology (large disc herniations occupying more than $50 \%$ of the spinal canal),

20) spinal stenosis,

21) dural fistula,

22) synovial cysts,

23) dysraphia

The following data was obtained from all participants using a predefined proforma. Age, sex, occupation, socioeconomic status, nature of trauma, comorbidities, clinical examination, radiological work up and informed written consent. Each procedure was carried out by a senior surgeon in the department of Orthopaedics. 30 cases of intervertebral disc prolapse, treated at the Orthopedic Department of GMC, Thrissur were included in the study

Epidural steroid injections were given through caudal route. Steroid used was TRIAMCINOLONE (TRICORT) $80 \mathrm{mg}$ and LIGNOCAINE (5\%) $2.5 \mathrm{ml}$ and diluting it with distilled sterile water up to $20 \mathrm{ml}$ of total volume.

\section{Procedure}

Local anaesthesia with $5 \%$ lignocaine at site of injection. The patient is positioned in a prone position to expose the sacral hiatus

Entry point: The entry point is the sacral hiatus

A 16 G I V cannula (stillette) was passed through the sacral hiatus after palpating it digitally. The I $\mathrm{V}$ cannula is advanced into the epidural space. Proper placement of cannula is confirmed by testing for no resistance.

After confirming the position of cannula a mixture of $80 \mathrm{mg}$ Triacinolone (steroid), $1.5 \mathrm{ml}$ of $5 \%$ lignocaine (local anaesthetic) and sterile water to make a total volume of $20 \mathrm{ml}$ is injected into the epidural space. 
Patient is then made lie on the side with symptomatic side as dependent position.

Successful injection is marked by

1) Injection of cocktail (mixture) without resistance, showing needle to be situated in epidural space.

2) Decrease in paresthesia to foot.

Patients were assessed using the Japanese Orthopedic Association Low Backache score.

\section{RESULTS}

\section{Age and sex Distribution}

We found that IVDP was common between the 4th and 5th decades of life sith mean age of 50 years. Female predominance was seen in our series i.e 18 of our patient were male $(60 \%)$ and 12 were male $(40 \%)$

\section{Occupation of patient}

In our series patient with Agriculture as occupation were $10(33.33 \%)$, mechanic 1 (3.33\%), house wife $8(26.66 \%)$, clerk $1(3.33 \%)$, merchant $4(13.33 \%)$, coolie $6(20 \%)$.

\section{Pre treatment symptoms}

In our series all $30(100 \%)$ patients had LBA and Radicular pain, 6 (20\%) patients had paraesthesia and $0 /$ no $(0 \%)$ patients had weakness and sensory loss.

TABLE - 1 Nerve tension signs

\begin{tabular}{|l|c|}
\hline SLRT & 3 \\
\hline LASEGUES TEST & 2 \\
\hline SLRT + LASEGUES TEST & 25 \\
\hline TOTAL & 30 \\
\hline
\end{tabular}

In our study $3(10 \%)$ were SLRT positive, 2 (6.66\%) patients were positive for Lasegues test and $25(83.33 \%)$ were positive for both.

In our series $0(0 \%)$ patients had JOA pre treatment scores between $0-3,0(0 \%)$ patients between 3-6, $19(63.33 \%)$ patients between 6-9, 8 (26.66\%) patients between 9-12 and 3 (10\%) patients between 12-15.

In our series $0(0 \%)$ patients had JOA post treatment score between $0-3,0(0 \%)$ patients between $3-6,1(3.33 \%)$ patients between 6-9, 0
(0\%) patients between 9-12 and 29 (96.66\%) patients between 12-15.

\section{Rate of improvement}

Japanese Orthopedic Association Score for Low Backache was used for evaluating the results.

TABLE - 2 Rate of improvement

\begin{tabular}{|l|c|}
\hline$<49 \%$ & 1 \\
\hline $50 \%-74 \%$ & 4 \\
\hline $75 \%-89 \%$ & 22 \\
\hline$>90 \%$ & 3 \\
\hline
\end{tabular}

Based on the above score, the final results were as follows:

$3(10 \%)$ patients had excellent results, $22(73 \%)$ patients had good results, $4(14 \%)$ patients had fair results and $1(3 \%)$ patient had poor results

\section{CONCLUSIONS}

Treating Intervertebral disc prolapse with a mixture of Epidural steroid (Triamcenolone 80 $\mathrm{mg}$ ) and Local anaesthetic (5\% lignocaine $1.5 \mathrm{ml}$ ) is a very effective and successful method.

Epidural Steroid and Local anaesthetic mixture is effective in controlling low backache and radicular pain caused by IVDP.

It allows the patient to go back to his / her work early as compared to other modalities of conservative treatment.

\section{DISCUSSION}

The treatment of intervertebral disc prolapse with a mixture of an epidural steroid and local anaesthetic is a very effective method of controlling symptoms of IVDP like low back ache and radiculopathy.

It is a non-invasive procedure and avoids risks of operative treatment with a good amount of patient satisfaction and symptomatic relief.

It decreases time and cost of treatment of IVDP for a longer duration of at least 12 weeks.

\section{REFERENCES}

1. Mixter W J, Barr J S, 1934: "Rupture of the interve rtebral disc with involvement 
of spinal canal" N Eng J Med,211:210-2 15.

2. Smith L; "Enzyme dissolution of nucleus pulposus in humans". JAMA 1964:187:137.

3. De Palma A, Rothman R: "Surgery of lumbar spine". C lin. Orthop.63: 1969;162-170.

4. Naylor A and Bradford: Late results of laminectomy for lumbar disc prolapsed, JBJS Vol.56B, No.1:1974; Pg17-29.

5. Erisk V. Spangfor: The lumbar disc herniation. A computer aided analysis of 2504 operations, Acta orthopaedics Scandinavia supplement. No 142:1972; Pg 5-79.

6. Salenius P, Laurent L E, 1977; "Results of operativ e treatment of huymbar disc herniation. A survey of 886 patients". Acta Or thop Scand, 48:630-4.

7. Rolf Hagen, Lars B: " Unilateral and bilateral part ial laminectomy in lumbar disc prolapsed:. Acta Orthop.Scand 48: 1977;41-48.

8. Weir B.K: “ A Prospective study of 100 lumbosacral discectomies". Journal of Neurosurg. 50: 1979;283-286.

9. Sharma S, Sankaran B, 1980; "A clinical profile of prolapsed lumbar intervertebral disc and its management". Indian Jou rnal of Orthopaedics, 14(2): 204-212.

10. Weber H, 1983; "Lumbar disc herniationA controlle $d$ prospective study with ten years of observation", Spine, 8:131-140.

11. Rish B.L: "A critique of surgical management of lum bar disc disease in a private neurosurgical practice", Spine 9:1984;500-5 03.

12. Lewis P.J, Weir B.K.A, Broad R.W, Grace M.G.: "Long term prospective study of lumbosacral discectomy:, J.Neurosurg. 67:1987;49-50.

13. Waddell G.. Reilly S., Torsney B et al: “ Assessmen $t$ of the outcome of low back surgery" J.Bone Joint Surg. 70-B:1988; 723-725.
14. Silvers H.R. 1988; "Microsurgical versus standard 1 umbar discectomy"; Neurosurgery: 22(5):837-841.

15. Sadashisa Hijikata: Percutaneous nucleotomy, a new concept techniques abd 12 year experience. CORR,No. 238:1989; Pg 9-23.

16. Bhalla R and A.K.S. Deane; The results of lumbar intervertebral disc surgery, Indian Journal of Orthopaedics, Vol.23,No.1:Jan 1989.

17. Gupta S.K. and Ved Prakash: Surgery in lesion of LIVD degeneration Indian journal of orthopaedics, Vol.23,No.1; 1989;Pg 44-49.

18. Harishchandra and K.P,Srivastava: An assessment of results of surgery in LBP \& Sciatica, Indian Journal of Orthopaedics, Vol.24,No.11:Jan 1990,Pg 86-88.

19. Spengler DM, Quellette E A, Battio M, Zeh J, 1990; "Elective discectomy for herniation of lumbar disc. Additional experience with an objective method", J Bone Joint Surgery America, 72 A (2): 23 0-32.

20. Thomas J Errico \& David F. Fardon: Open discectomy as treatment for herniated nucleus pulposus of lumbar spine. Spine Vol 20,No.16:1995; Pg 1829-1833.

21. Advances in endoscopic disc and spine surgery: foraminal approach. Yeung AT, Yeung $\mathrm{C}$ A. Arizona Institute for Minimally Invasive Spine Vol 20, No. 16:1995; Pg 1829-1823.

22. McCulloch J A, 1996; "Focus issue on lumbar disc he rniation : Macro \& Micro discectomy", Spine, 21 (24 suppl):453568.

23. Wang J C, Bohlman N H and Riew K D, 1998: "Dural te ars secondary to operation on the lumbar spine: Management and results after a two year minimum follow up of eighty patients",J Bone Joint Surgery A M, 80 A (12):A28-A32. 
24. Engene J Carragee, Michael Y.Han, Benjamin Yang, David H. Kim “ Activity restriction after posterior lumbar discectomy" a prospective study of outcomes in 152 cases with no post operative restriction. Journal Spine Vol.24, No.22: 1999:Pg 1952-1957.

25. Kaisuke Takahashi, Iwao shima "Nerve root pressure in lumbar disc herniation" Journal spine, Vol 24,No.19:1999; 20032006.

26. Fredman B, Nun MB, Zohar E, et al.(Feb 1999). "Epi dural steroids for treating "failed back surgery syndrome". : is fluor oscopy really necessary ?". Anesth Analg. 88 (2):367-72.

27. Gautam Bhattacharya, Arun Seal, N.D.Chaterjee, "Seg mental spinal decompression in lumbar spinal canal stenosis" foll owing long standing.

28. Varoomen PC, de Krom MC, Knottnerus JA (Feb 2002). "Predicting the outcome of sciatica at short- term follow-up". $\mathrm{Br} \mathrm{J}$ Gen Pract 52 (475): 119-23.

29. Wilco C.Peul, M.D., Hans C.Van Houwelingen, May 2007. "Surgery versus Prolonged Conservative Tratment for Sciatica". The New England Journal of Medicine; 356:2245-2256.

30. Morgan-Hough C V J, Jones P W and Eisenstein S M, 2002; "Primary and revision lumbar discectomy; A 16 year review from one center", $\mathrm{J}$ Bone Joint Surgery Br, 85 B(6): 871-874.

31. $\mathrm{T}$ obinick EL, Britschgi-Davoodifar $\mathrm{S}$ (Mar 2003). "P erispinal TNF-alpha inhibition for discogenic pain”. Swiss Med Wkly 133 (11-12): 170-7.

32. Carragee EJ (May 2005). "Clinical practice. Persist ent low back pain”. New England Journal of Medicine 352 (18): 1861-8.

33. McMillan MR, Crumpton C. Cortical blindness and neurologic injury complicating cervical transforaminal injection for cervical radiculopathy. Anesthesiology. 20063; 99:509-511.

34. Rozin L, Rozin R, Koehler SA, et al. Death during a transforaminal epidural steroid nerve root block (C7) due to perforation of the left vertebral artery. Am J Forensic Med Path.2003;24:351-355.

35. Tiso RL,Cutler T, Catania JA, Whalen K. Adverse central nervous system sequelae after selective transforaminal block: The role of corticosteroids. Spine J.2004; 4:468-474.

36. Brouwers PJAM, Kottnik EJBL, Simon MAM, Prevo RL. A cervical anterior spinal artery syndrome after diagnostic blockade of the right C6-nerve root.Pain.2001;91:397-399.

37. Baker R, Dreyfuss P, Mercer S, Bogduk N. Cervical transforaminal injection of corticosteroids into a radicular artery: A possible mechanism for spinal cord injry. Pain.2003;103:211-215.

38. Rathmell JR, Aprill C, Bogduk N. Cervical transforaminal injection of steroids. Anesthesiology. 2004;100:15951600.

39. Tiso RL, Cutler T, Catania JA, Whalen K. Adverse central nervous system sequelae after selective transforaminal block: the role of corticosteroids. Spine J. 2004; 4:468-474.

40. Derby, R, Date E, Lee CH, Lee JH, Jee $\mathrm{SH}$. Size and aggregation of corticosteroids used for epidural injections. Interventional Spine, ISIS Newsletter. 2005 5(4):30-37.

41. Okubadejo GO, Talcott MR, Schmidt RE, et al. Perils of intravascular methylprednisolone injection into the vertebral artery: an animal study.J. Bone joint Surg Am.2008;90:1932-1938.

42. Bogduk N, Dreyfuss P, Baker R, et al. Complications of spinal diagnostic and treatment procedures. Pain Med. 2008;9:S1134. 
43. LoD, Vallee JN, Spell L, et al. Unusual origin of the artery of Adamkiewicz from the fourth lumbar artery. Neuroradiology. 2002; $44: 153-157$

44. Eldin, N. N., and Senouci, A. B. (1993), "Rubber-Tyreparticles as concrete aggregate."Journal of Material inCivil Engineering, ASCE, 5(4), 478-496. 